\title{
CORRELATION BETWEEN WOOD DENSITY AND FIBER LENGTH WITH ESSENTIAL MACRO-NUTRIENTS ON BASE OF STEM OF Shorea leprosula and Shorea parvifolia
}

\author{
Rizki Maharani and Andrian Fernandes \\ Balai Besar Penelitian Dipterokarpa, Samarinda, Kalimantan Timur \\ Email : rizma_annisa@yahoo.com dan af.andrian.fernandes@gmail.com
}

\begin{abstract}
S. leprosula and S. parvifolia are widely developed as source of high quality wood. The quality of wood could be affected by nutrient elements. It is important to measure the nutrients contained in tree stem including wood density and fiber length due to their influence in tree growth. This research aims to know correlation between wood density and fiber length with distribution of essential macro-nutrients; N, P and K on stem base of $S$. leprosula and $S$. parvifolia trees. Wood density measurement followed DIN 2135 standard method, fiber length measurement followed FPL method, and nutrient measurement used AAS method. Further, the observation data was analyzed using SPSS 16 software. Wood density and fiber length on stem bases of both of tree species tended to increase radially from section nearby the pith to section nearby the bark respectively. Wood density of $S$. leprosula ranged from 0.333-0.362 with $1.279-1.343 \mu \mathrm{m}$ in fiber length, while wood density of $S$. parvifolia ranged from $0.285-0.346$ with $1.497-1.805 \mu \mathrm{m}$ in fiber length. Distribution of nutrient N, P and $\mathrm{K}$ of stem base from pith to bark also tended to increase. On S. leprosula, nutrient elements N, P, K had significant correlation with wood density and fiber length. On S parvifolia, nutrient elements N, P, K had a significant correlation with wood density. Meanwhile, nutrient elements N, P, K had a non significant correlation with fiber length.
\end{abstract}

Keywords : Shorea leprosula, Shorea parvifolia, base of the stem, wood quality distribution, nutrient distribution.

\section{INTRODUCTION}

Dipterocarpaceae is dominant tree family in lowland tropical rain forest of Southeast Asia. These trees have larger size than the others, so that it becomes one of high-value sawn timber (Breulmann et al., 1998). Some species of Dipterocarpaceae that have been developed are Shorea leprosula and Shorea parvifolia.

Tree growth is strongly influenced by the environment and nutrition. Richards (1992) explained that it is important to measure the nutrients contained in the tree based on age, size, fertilization and soil fertility. Tree nutrition information is mostly gained from leaves nutrition, while the nutritional content of stem is very rarely observed.

Wimmer (2002) explained that in each individual tree, encompass cells structure, tissues and organs are closely related to tree physiology and provide lots of information about its past life and environment. Some wood properties that can be analized are cell anatomy, cell dimension, micro fibril angle and wood density (Lasserre et al., 2009).

The aim of this research is to determine the distribution of wood density and fiber length and its correlation with the distribution of essential macro-nutrients (nitrogen, phosphorus and potassium) contained in the base of stem of S. leprosula and S. parvifolia. 


\section{MATERIALS AND METHODS}

Disc samples of stem base of $S$. leprosula and $S$. parvifolia have $40 \mathrm{~cm}$ of diameter and $20 \mathrm{~cm}$ of cutting thickness. These samples were taken from the area of RKT 2011 IUPHHK PT. Gunung Gajah Abadi, Muara Wahau, East Kutai, East Kalimantan. Each disc was made into $X$ axis as shown below.

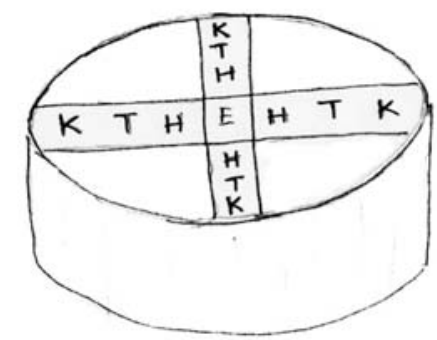

Caption : E : empulur/pith $\mathrm{T}$ : tengah $/ \mathrm{mid}$

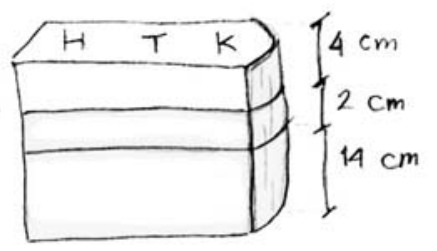

$4 \mathrm{~cm}$ : fiber length measurement

$2 \mathrm{~cm}$ : wood density measurement

$14 \mathrm{~cm}$ : macro-nutrients measurement

Figure 1. Sampling test on stem base of S. leprosula and S. parvifolia.

Measurement of wood density and fiber length was held in Laboratory of Forest Products Technology, Dipterocarps Research Center, Samarinda, East Kalimantan. The air-dried wood density measurement followed DIN 2135 Standard Method (DIN, 1975). Maceration and fiber length measurements followed the method of Forest Products Laboratory (1960). Measurement of macro-nutrients in stem base was conducted at the Laboratory of Soil, Pusrehut, Unmul, Samarinda, East Kalimantan, with spectrophotometric method. Further, the data was analyzed using SPSS 16 software.

\section{RESULT AND DISCUSSION}

Distribution of wood density, fiber length and macro-nutrients on stem base of $S$. leprosula and S. parvifolia can be seen in this following table.

Tabel 1. Distribution of wood density, fiber length and macro-nutrients on stem base of of S. leprosula

\begin{tabular}{llllll}
\hline & \multirow{2}{*}{ Wood density } & Fiber length $(\mu \mathrm{m})$ & \multicolumn{3}{c}{ Macro-nutrients } \\
\cline { 4 - 6 } & & 1.279 & $\mathrm{~N}(\%)$ & $\mathrm{P}(\%)$ & $\mathrm{K}(\%)$ \\
\hline Pith & 0.333 & 1.303 & 0.115 & 0.0015 & 0.050 \\
Mid & 0.339 & 1.343 & 0.160 & 0.0055 & 0.111 \\
Bark & 0.362 & 0.180 & 0.0085 & 0.471 \\
\hline
\end{tabular}

Tabel 2. Distribution of wood density, fiber length and macro-nutrients on stem base of S. parvifolia.

\begin{tabular}{lccccc}
\hline & \multirow{2}{*}{ Wood density } & Fiber length $(\mu \mathrm{m})$ & \multicolumn{3}{c}{ Macro-nutrients } \\
\cline { 4 - 6 } & & & $\mathrm{N}(\%)$ & $\mathrm{P}(\%)$ & $\mathrm{K}(\%)$ \\
\hline Pith & 0.285 & 1.497 & 0.120 & 0.005 & 0.083 \\
Mid & 0.312 & 1.679 & 0.130 & 0.005 & 0.103 \\
Bark & 0.346 & 1.805 & 0.210 & 0.011 & 0.613 \\
\hline
\end{tabular}


Martawijaya et al. (1981) mentioned that wood density of $S$. leprosula ranged from 0.30 - 0.86 with a fiber length of $1352 \mu \mathrm{m}$. The result in Table 1 indicated that wood density and fiber length of $S$. leprosula tended to increase radially from section nearby the pith to section nearby the bark. Shmulsky \& Jones (2011) stated that wood density and fiber length have variations radially, from nearby the pith to nearby the bark and tend to increase until the wood passing the juvenile period.

Antikainen et al. (2004) explained that there are two types of nutrient cycles that are not only influenced by living organisms, but also influenced by human activity, namely nitrogen and phosphorus cycles. Although the amount of nitrogen and phosphorus content in the wood is small compared to the bark that can reach $40 \%$, this nutrient is greatly affects the quality of the wood. Shmulsky and Jones (2011) showed that the nitrogen $(\mathrm{N})$ in the wood is $0.1 \%$ from its dry weight. While potassium $(K)$ in the wood is found in the form of inorganic compounds, usually as component of ash content.

From Table 1 it can be seen that the distribution of macro-nutrients such as nitrogen, phosphorus and potassium on stem base of $S$. leprosula showed a rising trend radially from nearby pith to nearby bark sections. Rothpfeffer and Karltun (2007) explained that the nutrient concentration on base of the stem has wide variations, generally heartwood section has lower concentration than the sapwood.

Further observational data was analyzed to observe the correlation between macronutrient factors (N, P and K) in wood with wood quality (wood density and fiber length). The data was analyzed using SPSS 16 software as described in the following table.

Tabel 3. Correlation between wood density and fiber length with macro-nutrients on stem base of S. leprosula.

\begin{tabular}{ccc}
\hline \multirow{2}{*}{ Macro-nutrients } & \multicolumn{2}{c}{ Correlation } \\
\cline { 2 - 3 } & Wood density & Fiber length \\
\hline Nitrogen & $0.85 \mathrm{~s}$ & $0.91 \mathrm{~s}$ \\
Fosfor & $0.91 \mathrm{~s}$ & $0.90 \mathrm{~s}$ \\
Kalium & $0.99 \mathrm{ss}$ & $0.87 \mathrm{~s}$ \\
\hline Remarks : s=significant & & ss = very significant
\end{tabular}

Tabel 4. Correlation between wood density and fiber length with macro-nutrients on stem base of S. parvifolia.

\begin{tabular}{ccc}
\hline \multirow{2}{*}{ Macro-nutrients } & \multicolumn{2}{c}{ Correlation } \\
\cline { 2 - 3 } & Wood density & Fiber length \\
\hline Nitrogen & $0.91 \mathrm{~s}$ & $0.81 \mathrm{~ns}$ \\
Fosfor & $0.86 \mathrm{~s}$ & $0.73 \mathrm{~ns}$ \\
Kalium & $0.89 \mathrm{~s}$ & $0.78 \mathrm{~ns}$ \\
\hline Remarks : s=significant & & ss = very significant
\end{tabular}

Table 3 showed that all nutrients ( $\mathrm{N}, \mathrm{P}$ and $\mathrm{K}$ ) had positive correlation. Nutrients increased from nearby pith to nearby bark radially, followed by the increasing of wood density and fiber length. There was a highly significant correlation, between potassium and wood density on stem base of $S$. leprosula. 
Beets et al. (2001) explained that wood density is influenced by genetic factors, climate and soil. The increasing of nitrogen although in small amounts has a significant effect on wood density. The increasing of wood density can increase the number and length of fiber.

Table 4 showed that the fiber length of $S$. parvifolia had a non significant correlation to the macro-nutrients (nitrogen, phosphorus and potassium). This was consistent with the results of Ikonen et al. (2008) which stated that the relationship model of fiber length distribution is not significantly due to changes in nutrients on Pinus sylvestris and Picea abies, but it was caused by the cambium growth. Cambium growth in forming cell dimensions of the stem is likely influenced by hormonal activity in plants (Elo et al., 2009).

\section{CONCLUSION}

Distribution of macro-nutrients radially contained on stem base gave a positive correlation to the wood quality, wood density and fiber length. In general, nutrient distribution had an increasing tendency radially from the pith, mid and bark respectively. Further analysis showed that the nutrient distribution had a significant positive correlation to the wood density from both of test samples. Meanwhile, the nutrient distribution of fiber length indicated different analysis results from both of test samples. Significant positive correlations obtained from the test sample of $S$. leprosula, while the results were non-significant positive correlation obtained from the test sample of $S$. parvifolia. However, the tested parameters can be considered in the observation of wood quality, although it is still in limited number of test parameters. Some other parameters, such as the cambium growth and hormonal activity are worth considering as the parameter for further testing.

\section{REFERENCES}

Antikainen, R., R. Haapanen, and S. Rekolainen. 2004. Flows of Nitrogen and Phosphorus in Finland - The Forest Industry and Use of Wood Fuels. Journal of Cleaner Production. Vol. 12. Pp. 919-934. Elsevier.

Beets, P. N., K. Gilchrist, and M. P. Jeffreys. 2001. Wood Density of Radiata Pine : Effect of Nitrogen Supply. Forest Ecology and Management Journal. Vol. 145. Hal 173-180. Elsevier.

Breulmann, G., K Ogino, I. Ninomiya, P. S. Ashton, I. V. L. Frankie, U. S. Leffler, V. Weckert, H. Lieth, R. Konschak, and B. Markert. 1998. Chemical Characterisation of Dipterocarpaceae by Use of Chemical Fingerprinting - A Multielement Approach at Sarawak, Malaysia. The Science of the Total Environment Journal. Vol. 215. Hal 85100. Elsevier.

Elo, A., J. Immanen, K. Nieminen, and Y. Helariutta. 2009. Stem Cell Function During Plant Vascular Development. Seminars in Cell and Developmental Biology Journal. Vol. 20. Hal. 1097-1106. Elsevier.

Ikonen, V P., H. Peltola, L. Wilhelmsson, A. Kilpelainen, H. Vaisanen, T. Nuutinen, and S. Kellomaki. 2008. Modelling the Distribution of Wood Properties Along the Stem of Scots Pine (Pinus sylvestris L.) and Norway Spruce (Picea abies (L.) Karst.) as Affected by Silvicultural Management. Forest Ecology and Management Journal. Vol. 256. Hal 13561371. Elsevier. 
Lasserre, J P., E.G. Mason, M.S. Watt, and J.R. Moore. 2009. Influence on Initial Planting Spacing and Genotype on Microfibril Angle, Wood Density, Fibre Properties and Modulus of Elasticity in Pinus radiate D. Don Corewood. Forest Ecology and Management Journal. Vol. 258. Hal 1924-1931. Elsevier.

Martawijaya, A., I. Kartasujana, K. Kadir, and S. A. Prawira. 1981. Atlas Kayu Indonesia, Jilid I. Balai Penelitian Hasil Hutan. Bogor.

Richards, N. K. 1992. Cashew Tree Nutrition Related to Biomass Accumulation, Nutrient Composition and Nutrient Cycling in Sandy Red Earth of Norther Territory, Australia. Scientia Horticulturae Journal. Vol. 52. Hal 125-142. Elsevier.

Rothpfeffer C., and E. Karltun. 2007. Inorganic Elements in Tree Compartments of Picea abies - Concentrations versus Stem Diameter in Wood and Bark and Concentrations in Needles and Branches. Biomass and Bioenergy Journal. Vol. 31. Hal 717-725.

Shmulsky, R., and P. D. Jones, 2011. Forest Products and Wood Science, An Introduction, Sixth Ed., Wiley-Blackwell, Oxford, UK.

Wimmer, R. 2002. Wood Anatomical Features in Tree-rings as Indicator of Environmental Change. Dendrochronologia Journal. Vol. 20. Hal 21-36. Elsevier. 